\title{
骨骾細胞を用いた二次的血管柄付き移植骨片作製に関する実験的研究
}

\author{
福田あおい・森田章介
Experimental study of prefabricated vascularized bone graft using bone marrow cells

\author{
FUKUDA Aoi · MORITA Shosuke
}

\begin{abstract}
Vascularized bone grafts have been widely used to replace bone lost by disease or trauma. While this approach has been generally successful, some problems remain. Autologous bone grafts are limited in supply and can occasionally cause severe surgical trauma. Recently, some studies were undertaken to evaluate the potential of using cultured cells and biomaterials to produce tissue-engineered bone.

We created prefabricated vascularized bone grafts in the femur of rats by the combined use of a collagen sponge scaffold, osteoblasts differentiated from rat bone marrow, and a vascular bundle in a diffusion chamber. In the experimental group, the saphenous vessels of 8-week-old Fischer rats were exposed under general anesthesia and placed on slits cut into the diffusion chamber. Then, a collagen sponge scaffold seeded with osteoblasts was packed into the diffusion chamber. In the control group, the procedure was similar, without the placement of vessels. One, 3, 6, and 9 weeks after operation, the implants were harvested, and new bone formation was assessed histologically and biochemically.

In the experimental group, histological analysis showed active bone formation in the diffusion chamber. Bone formation was confirmed by the presence of osteoblasts lining the surface of new bone. Substantial alkaline phosphatase activity in the composites was detected soon after the procedure. Osteocalcin, detected immediately after implantation, increased slightly later. In contrast, there was no significant bone formation in the control group.

These results suggest that the combination of a collagen scaffold, osteoblasts, and a vascular bundle in the chamber may be a useful method for the prefabrication of vascularized bone grafts.
\end{abstract}

Key words: prefabricated vascularized bone graft (二次的血管柄付き移植骨片)， bone marrow cells（骨髄細胞）， tissue-engineered bone (再生培養骨), collagen sponge scaffold (コラーゲンスポンジの足場), diffusion chamber (diffusion chamber)

緒 言

口腔罯顔面領域において, 腫瘍の外科的切除や外傷など により生じた欠損を骨組織で再建する症例は多く，自家骨 移植が頻用されている。しかし，自家骨移植は健常組織に 侵襲を加えるうえ，骨採取部位が限定され，採取量にも制 限があるという問題を残している ${ }^{1 \sim 5)}$ 。そこで自家骨に かわり自家の細胞と生体材料とを複合させた tissue engineering ${ }^{6)}$ による培養骨の作製が注目されるようになり,

大阪菌科大学口腔外科学第 1 講座

（主任：森田章介教授）

First Department of Oral and Maxillofacial Surgery, Osaka Dental University (Chief: Prof. MORITA Shosuke)

受付日：2004 年 5 月 20 日

採択日：2004 年 7 月 27 日
再生医療として実用化されつつある ${ }^{7)}$ 。しかし，母床骨が 放射線照射を受けたり，周囲組織に良好な血行がない場合， 培養骨単体では確実な生着は期待できない，また，移植骨 は将来的に自己の骨組織に完全に置換されることが望まし い. そこで，悪条件下でも確実に生着する移植骨片の作製 が求められる。 今回, 健常組織への侵襲を軽減し，かつ適 切な大きさと形態を保持させ，さらに旺盛な骨形成が期待 できる二次的血管柄付き移植骨片の作製を, tissue engineering の技法を駆使してラット生体内で試みた。本研究 では，ラット骨髄由来の骨芽細胞をコラーゲンスポンジと ともに，骨形成のスペース確保を目的としたdiffusion chamber ${ }^{8 \sim 14)}$ 内に移植し，さらに血管束を組み合わせた. そして，その骨形成能や形成過程について経時的に観察し たので報告する。 

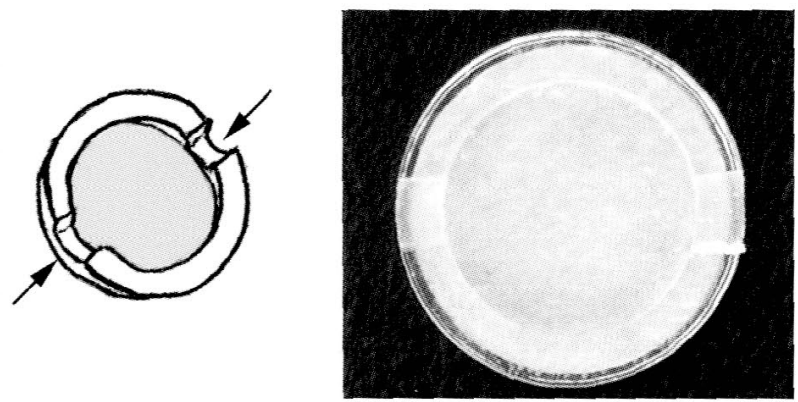

図 1 diffusion chamber の準備

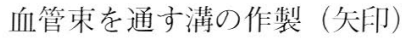

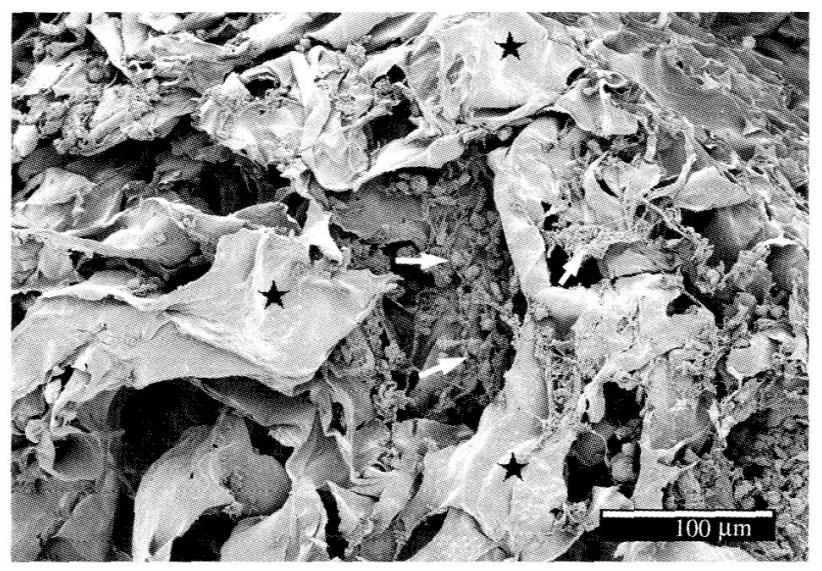

写真 1 細胞/コラーゲン複合体の電子顕微鏡写真 細胞 (知印)、コラーゲン（れ）

材料と方法

\section{1. 実験動物}

フィッシャ一系雄性ラット（清水実験材料，京都）を用 いた，骨髄細胞の採取には 3 週歯，体重 30 ～50g を合計 60 匹，移植実験には 8 週齢，体重 $140 \sim 160 \mathrm{~g}$ 合計 60 匹 用いた。そのうち組織学的観察のために各週 6 匹ずつ計 30 匹，また生化学的観察のために各週 6 匹ずつ計 30 匹用い た。な扎これらラット大腿骨の左側を実験群，右側を対照 群として実験を行った (後述)。飼育は大阪料科大学中内 柬学研究所動物施設の恒温窒 $\left(21 \pm 0.5{ }^{\circ} \mathrm{C}\right)$ で行い，飼料 はオリエンタル固形飼料 MF（オリエンタル酵母工業，東 京）を与えた。

\section{2. diffusion chamber}

diffusion chamber ring ${ }^{\circledR}$ (外径 $14 \mathrm{~mm}$, 内径 $10 \mathrm{~mm}$, 厚さ $2 \mathrm{~mm}$, Millipore Corporation, Sydney, 以下 diffusion chamberとする）の片面にフィッシャーバー（\#703）で血管 束通す溝作製し，その反対面に付属の MFセメント (Millipore Corporation, Sydney) を用いてメンブレンフィ ルター ${ }^{\circledR}(0.45 \mu \mathrm{m} \phi$, Millipore Corporation, Sydney) を接 着（図 1）した後，エチレンオキサイトガス滅菌を行った。

\section{3. 骨髄細胞の採取および培羪}

人腿骨より骨髅細胞老採取し，それら老 $15 \%$ 牛胎仔血 清打よび抗菌薬（ペニシリン $1000 \mathrm{U} / \mathrm{ml}$ ，ストレプトマイ シン $0.1 \mathrm{mg} / \mathrm{ml}$ ，アンホテリシン B $0.25 \mu \mathrm{g} / \mathrm{ml}$ ) 在添加した Minimum Essential Medium（MEM）培地を用い, $37^{\circ} \mathrm{C}$, $5 \% \mathrm{CO}_{2}$ 条件下で 10 日間初代培養を行った。只の後，トリ プシン-EDTA 処理により細胞暞濁液を作製し，細胞濃度を $1 \times 10^{6} \mathrm{cells} / \mathrm{ml}$ に調整した ${ }^{15 〜 18)}$ 。これを $18 \mathrm{G}$ 針付シリ ンジにて真皮久損用グラフト（テルダーミス ${ }^{\circledR} ，$ テルモ株 式会社，束宗）に注入することにより，細胞/コラーゲン複 合体を作製した（図 2)。そして上記培地に $10^{-8} \mathrm{M}$ デキサ メタゾン, $10 \mathrm{mM} \beta$-グリセロリン酸, $50 \mu \mathrm{g} / \mathrm{ml}$ アスコルビ
ン酸を加え, 練胞/コラーゲン複合体を 14 日間継代培養し た（写真 1 )。な打培地交換は 3 回/週行った。

\section{4. 実験方法}

ペントバルビタールナトリウム（ネンブタール ${ }^{\circledR}$, 大日 本製薬，大阪）の腹腔内投与による全身麻䣷下で，鼠径部 から足根部にかけて皮膚切開を行い，伏在動・静脈（以下， 血管束とする）を剖出し 19２2），あらかじめ用意しておい た diffusion chamberに血管束を通し，細胞/コラーゲン複 合体を充填した。その後，メンブレンフィルターをリング 上面に接着し移植材料を封入した（以下，実験群とする。 図 2, 写真 2)。一方，刘照として血管束を用いない群を作 製し，同部位に細胞/コラーゲン複合体を移植した（以下， 対照群とする)。最後に実験群，刘照群ともに，皮下組織な らびに皮膚縫合を行い閉創した。な打而群でdiffusion chamber内に形成された組織を移植片と呼ぶ。

\section{観 察 方 法}

移植後 $1 ， 3 ， 6$ 打よび 9 週にペントバルビタールナトリ ウム腹腔内投与による全身麻酔下で，腹大動脈にカテーテ 儿在抑入し末梢側をへパリン加生理食塩水にて灌流後, $10 \%$ 中性緩衝ホルマリン液で灌流固定した。そして，移植 片を摘出し，以下の方法で観察した。

\section{1. 肉眼的観察}

鼠径部から足根部にかけて皮膚切開を行い，移植片を観 察した。

\section{2.軟 $X$ 線による観察}

軟 X 線発生装置 CBM-2 ${ }^{\circledR}$ (Softex 社，東京）にて，管電 圧 $25 \mathrm{kV}$ ，管電流 $15 \mathrm{~mA}$ および照射時間 25 秒の条件で撮影 した. 


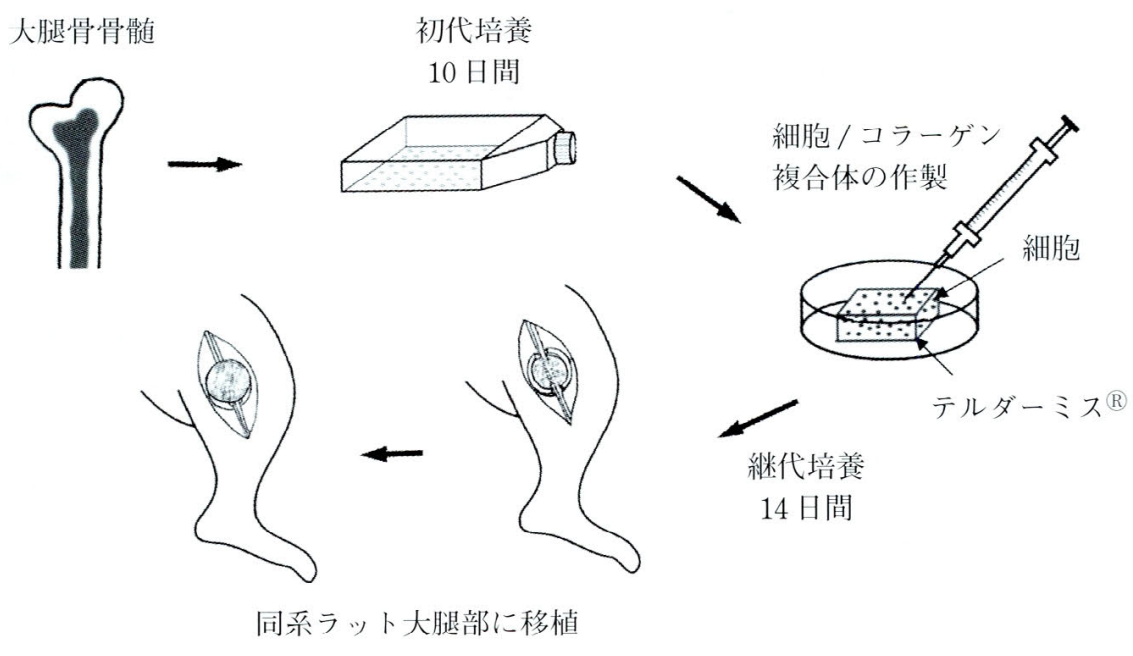

図 2 実験方法の模式図
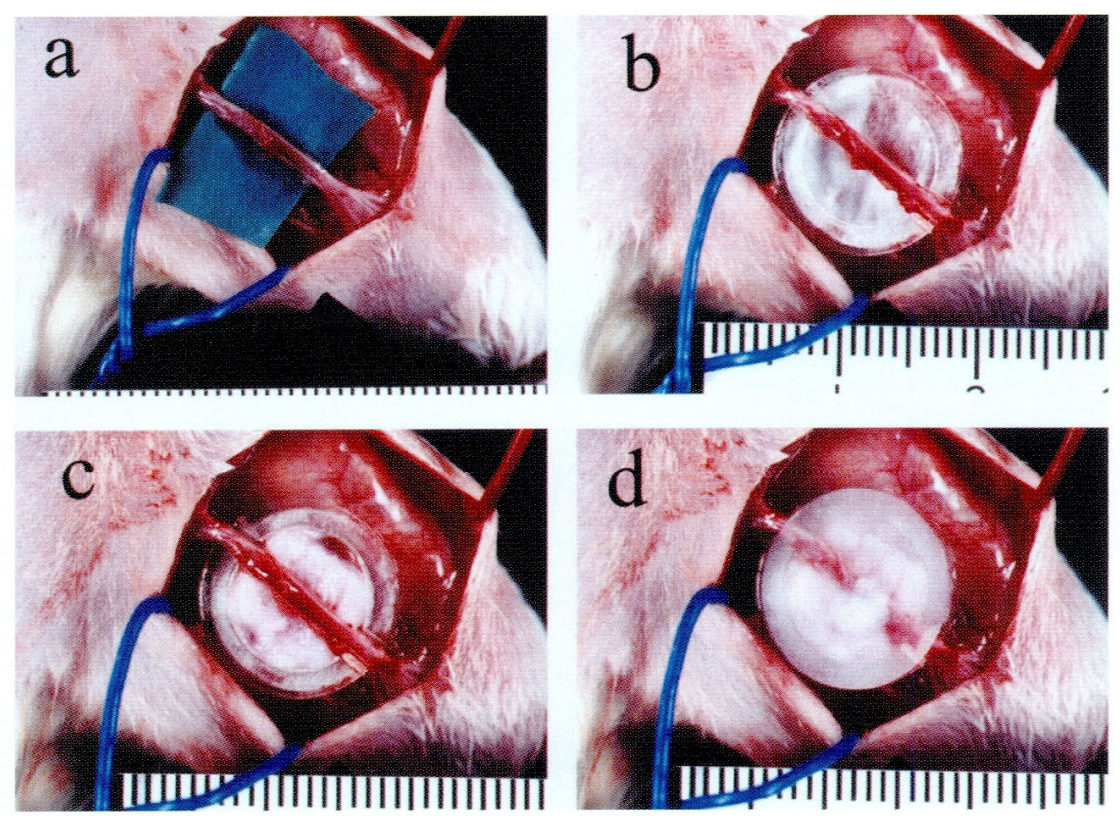

写真 2 血管束を用いた実験写真

a. 伏在動 · 静脈 (血管束) の剖出 b. 血管束への diffusion chamber の通合

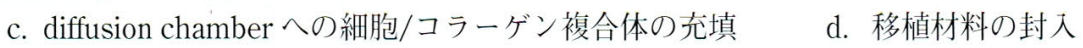

\section{3. 組織学的観察}

移植片を $10 \%$ 中性緩衝ホルマリン液にてさらに7日間 浸漬固定後，10\%ギ酸液にて 10 日間脱灰し，通法に従い 厚さ $3 \mu \mathrm{m}$ のパラフィン切片を作製した。吕してへマトキ シリン・エオジン染色（以下，H-E染色とする）を施し鏡 検した。

\section{4. 免疫組織化学的観察}

厚さ $3 \mu \mathrm{m}$ に薄切したパラフィン切片を脱パラフィン後,
$0.1 \%$ \%リプシン处理を行った.ついで $3 \%$ 過酸化水素水 加 PBS で内因性ペルオキシダーゼ活性を除去した。1次抗 体にはマウス抗オステオカルシンモノクローナル抗体 (OC4-30：タカラバイオ，京都）を用いた。 切片をそれぞ れ 1 次抗体に反応させた後, 2 次抗体として Envision ${ }^{\mathrm{TM}}+$ System HRP Mouse（K4000：DAKO，京都）を反応させ3， 3'-diaminobenzidine-tetrahydrochloride（DAB）で発色さ せた.さらにへマトキシリンによる核染色を行い, 脱水後 
透徹，封入した，免疫反応の刘照実験として，1次抗体の代 わりに非免疫血清を用い, 上記と同様の免疫組織化学的染 色を行い比較した。

\section{5. 生化学的観察}

移植後 3 日と $1 ， 3 ， 6$ および 9 週に灌流固定後，移植片

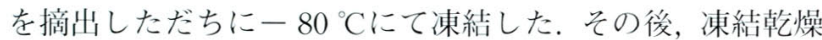

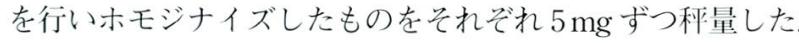

1) ALP 活性の測定

科量した移植片を $0.2 \%$ IGEPAL CA-630 および $1 \mathrm{mM}$ $\mathrm{MgCl}_{2}$ を含む $10 \mathrm{mM}$ Tris- $\mathrm{HCl}$ （pH7.5）中にて 1 時間攪抖 し，その上清を用いALP 治性の测定を p-nitrophenyl phosphate 法 ${ }^{23)}$ にて行った。

2) オステオカルシン（以下，OCとする）含有量の定量

秤量した移植片を $10 \%$ ギ酸液にて， $4{ }^{\circ} \mathrm{C} て ゙ 1$ 週間脱疢し た。孚の脱灰抽出液を Sephadex ${ }^{\circledR}$ G-25 (Amersham

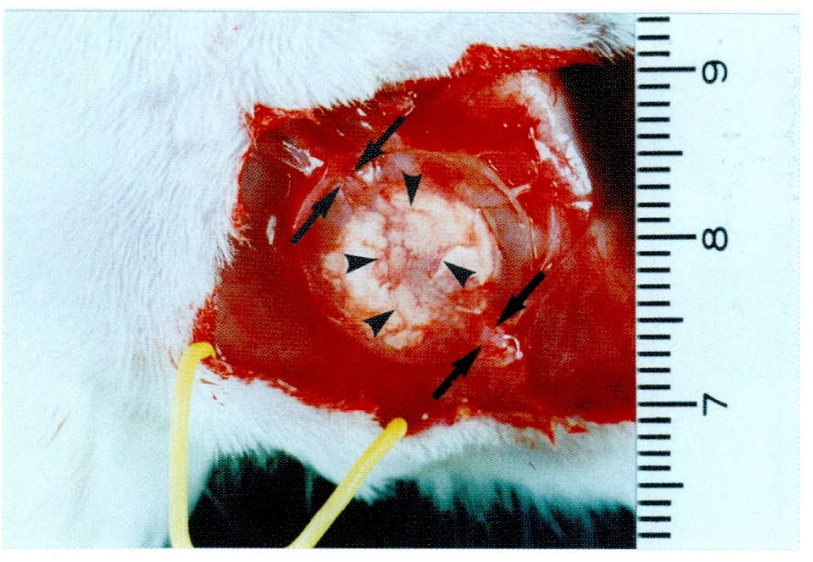

写真 3 実験群, 術後 9 週の移植片の肉眼写真 diffusion chamber形態に一致した骨形成および血管束 (矩印) から派生した新生毛細血管網（矢頭）がみられる。
Pharmacia Biotech, MA, USA) にて脱塩後, 凍結乾燥し, 酵素抗体法（ELISA）を用いて OC 含有量の定量を行った ${ }^{24)}$.

\section{結}

果

\section{1. 肉眼的所見}

実験群：術後 1 週では移植片はdiffusion chamberの形 態をしていたが，硬さは軟性であった。術後 3 週以降にな ると，移植片は diffusion chamber 形態にほぼ一致した骨様 組織となり，その表面には血管束から派生した毛細血管網 が認められた（写真 3 )。

対照群：観察期間中, 移植片は diffusion chamber の形態 をしていたが，硬さは軟性であった，

\section{2 。軟 X 線による所見（写真 4 ）}

実験群：術後 1 週ではX 線不透過像が移植片内に散在 し，とくに血管束の走行に一致して明瞭であった。術後 3 週では移植片のほぼ全体にX 線不透過像がみられ，術後 6 週では移植片全体のX 線不透過性が増強していた。術後 9 週では不透過像が全体的に減少していたが，とくに血管束 周囲の不透過性が低下していた。

対照群：術後 1 週では X 線不透過像はほとんどみられな かった. 術後 3 週以降ではX線不透過像がわずかに確認で きたが，実験群に比べ著しく少なかった。

\section{3 . 組織学的所見}

実験群：術後 1 週では移植片周辺にコラーゲンが残存し ていたが，血管束周囲には幼弱な骨形成が認められた（写 真 5)。術後 3 週では局所的にコラーゲンが残存していた が，移植片中央部や周辺に旺盛な骨形成がみられた（写真 6). 術後 6 週になるとコラーゲンはほとんど認められず, 移植片周辺に形成された骨はリモデリングとともに成熟 し, 骨髄組織も一部みられるようになった (写真 7 )。術後
1 週

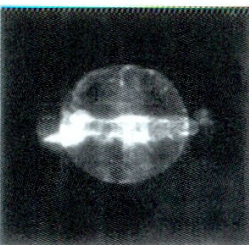

対照群

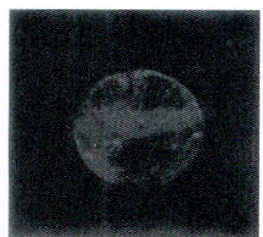

3 週
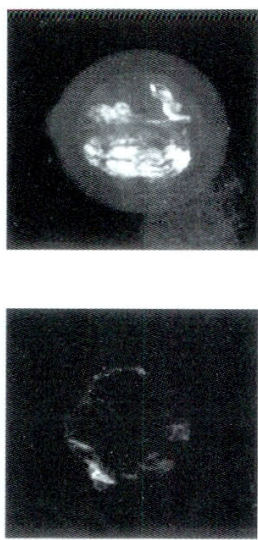

6 週
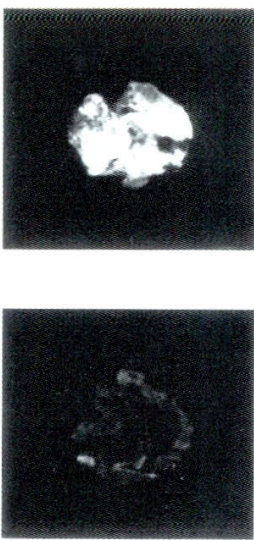

9 週
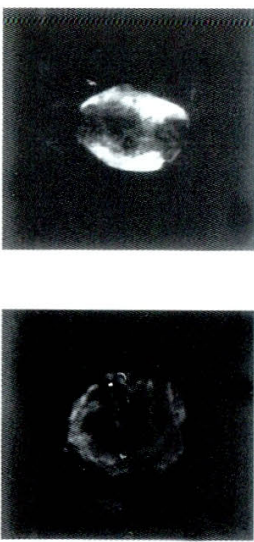

写真 4 軟 X線宁真 

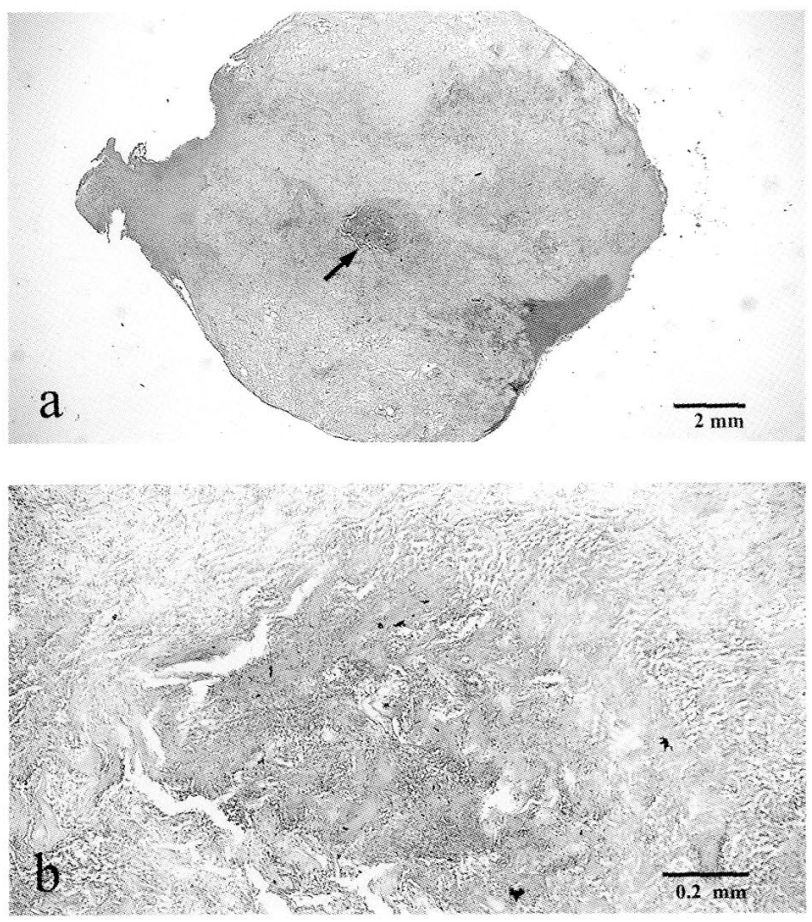

写真 5 实験群, 術後 1 蔨の H-E 染色写真 $\mathrm{b}$ は $\mathrm{a}$ の矢印部の桩大.

幼弱な骨形成がみられる。
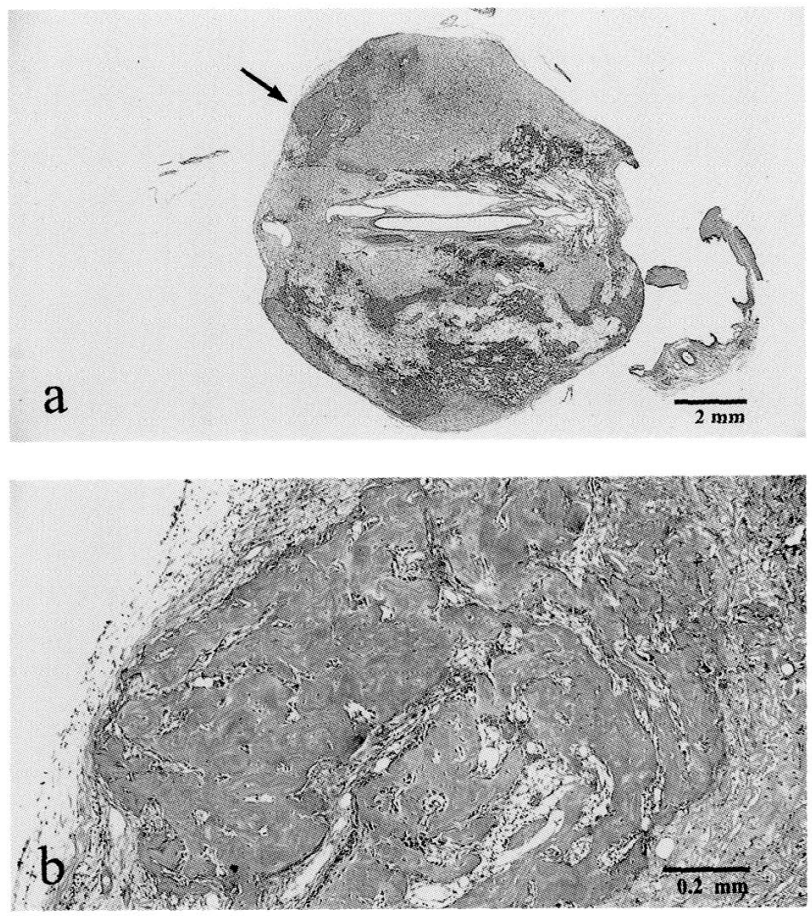

写真 6 実験群, 術後 3 週の H-E 染色写真 b はaの知印部の搪大。 昨盛な骨形成がみられる。
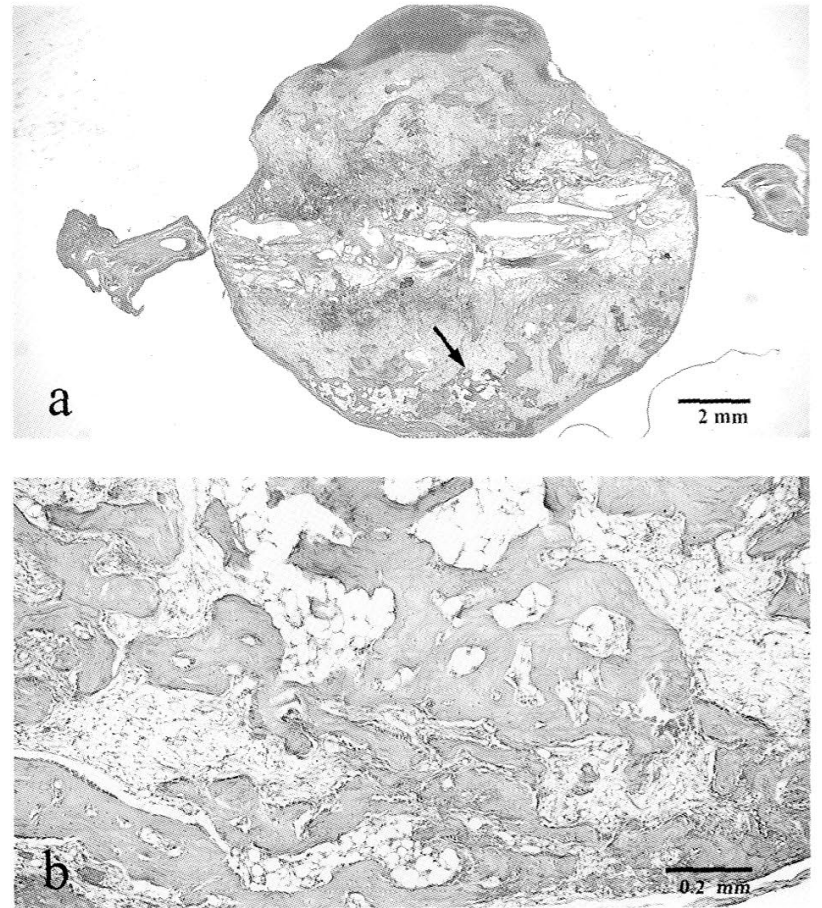

写真 7 実験群, 術後 6 週の H-E 染色写真 $\mathrm{b}$ 法aの知印部の搪大.

成熟した骨と骨髄がみられる。
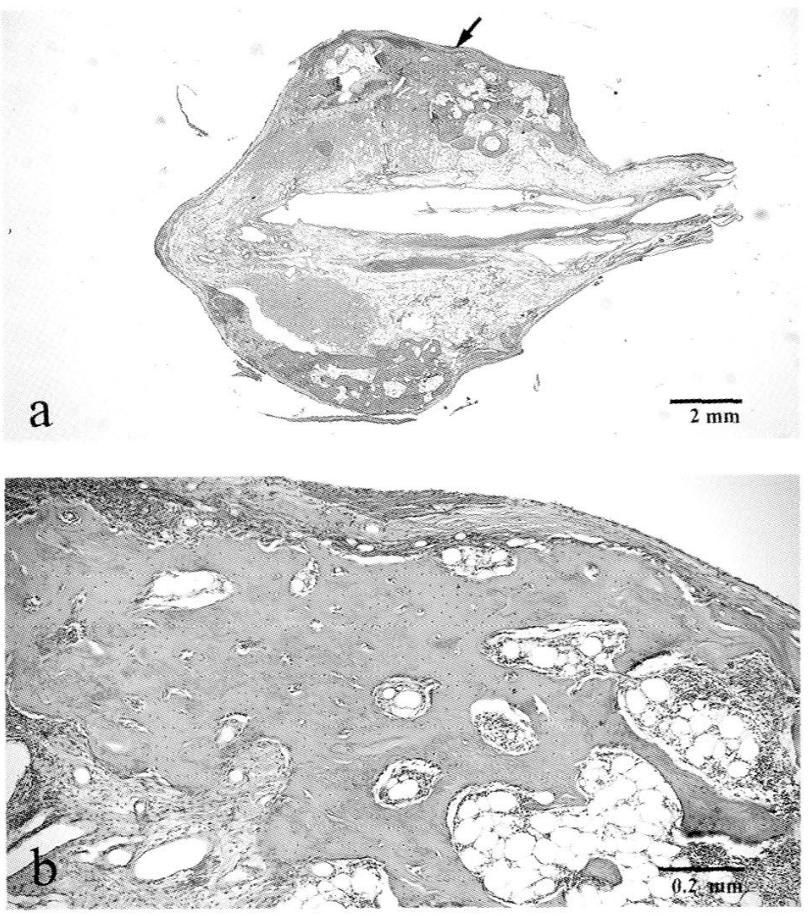

写真 8 実験群, 術後 9 䓢の H-E 染色写真 b は $\mathrm{a}$ の矢印部の搪大. さらに成熟した骨組織がみられる。 


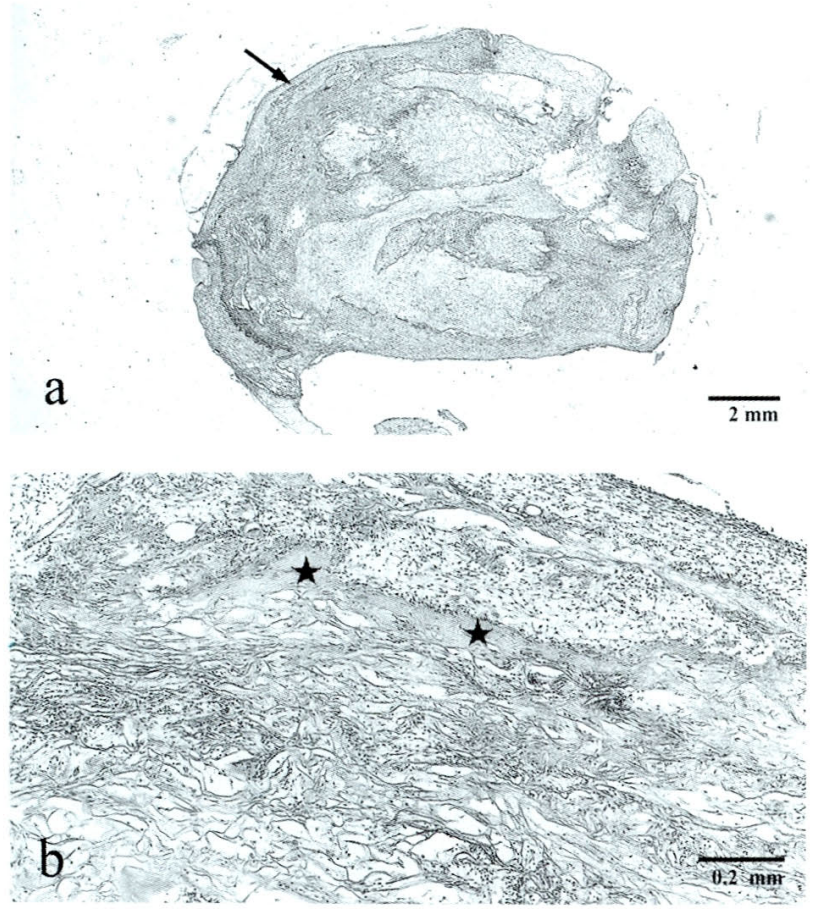

写真 9 対照群, 術後 3 週の H-E 染色写真

$\mathrm{b}$ は $\mathrm{a}$ の知印部の拡大.

全体的にコラーゲンがみられる。

骨形成がわずかにみられる（れ）。

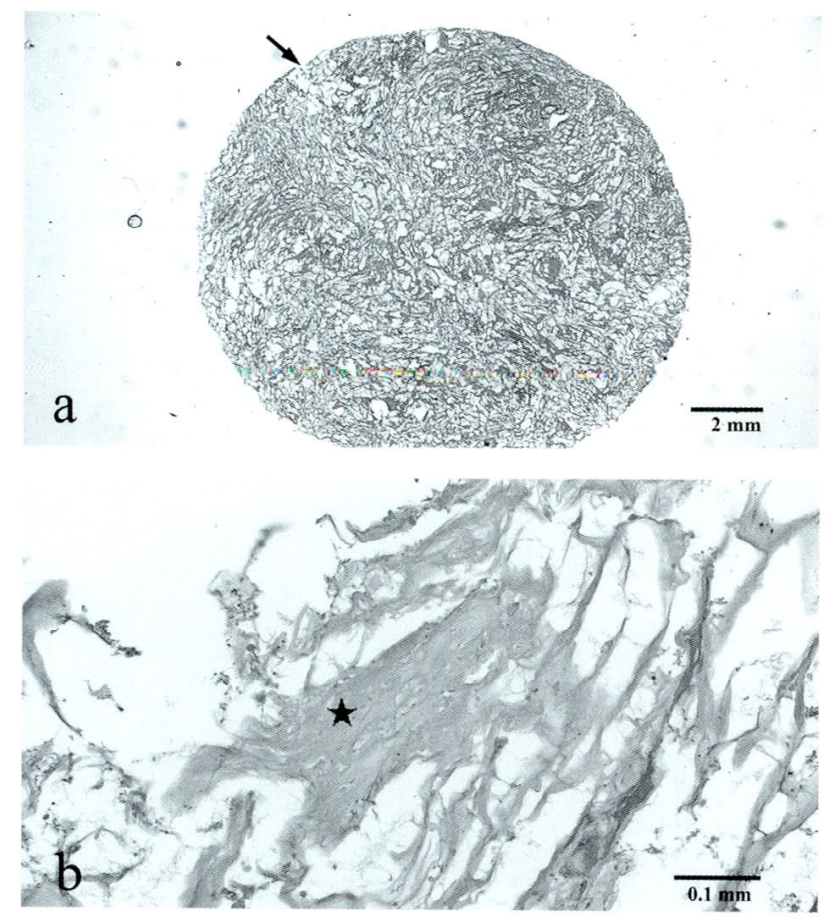

写真 10 対照群, 術後 9 週の H-E 染色写真

$\mathrm{b}$ は a の矢印部の拡大.

全体的にコラーゲンがみられる。

骨形成がわずかにみられる

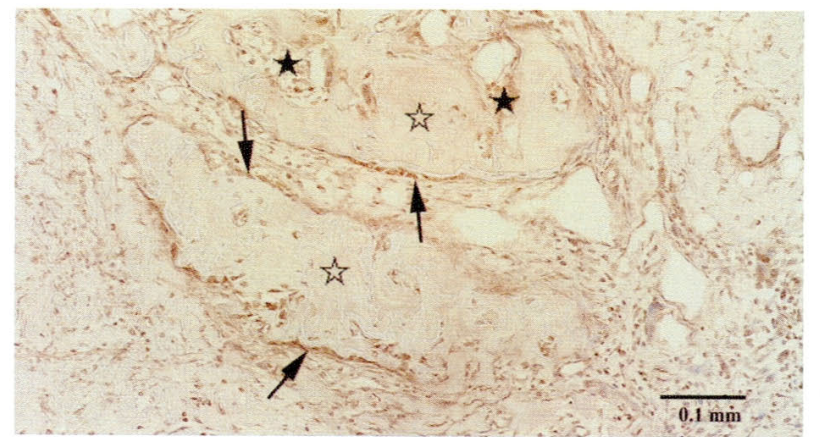

写真 11 尖験群, 術後 3 週の免疫組織化学染色写真 新生された骨基質（え），扰よびそれに接した骨芽細胞 (矢印)，骨髄細胞（れ）に抗 OC 抗体陽性所見がみら れる。

1 週打よび 3 週でみられた血管束周囲の骨は減少傾向にあ り，同部では管腔形成が多くみられるようになった。術後 9 週では 6 週とほぼ同様な所見を示していたが，術後 6 週 に比べ移植片中央部ではさらに吸収傾向にあった（写真 8).

対照群：各週で移植片全体にコラーゲンがみられ，骨形 成はわずかしか認められなかった（写真 9,10$)$.

\section{4. 免疫組織化学的所見}

実験群：術後 1 週では新生された骨基質およびそれに接 した骨芽細胞に抗 OC 抗体陽性所見がみられた。術後 3,6 および 9 週になるとさらに骨髄組織にも陽性所見がみられ た (写真 11).

対照群：術後 1 週では強い抗 OC 抗体陽性所見はみられ なかった. 術後 3,6 および 9 週では一部の骨様組織と思わ れる部位に陽性所見がみられた。

\section{5 . 生化学的所見}

1) ALP 活性の測定

実験群: 術後 3 日で $8 \mathrm{IU} / \mathrm{mg}$ と上昇したが, 術後 1 週以 降は約 $5 \mathrm{IU} / \mathrm{mg}$ であった（図3).

対照群：術後 1 週で $7.5 \mathrm{IU} / \mathrm{mg}$ と上昇したが, 術後 3 週 以降は実験群と同様に約 $5 \mathrm{IU} / \mathrm{mg}$ であった。

2) OC 含有量の定量

実験群 : 術後 3 日で $4 \mathrm{ng} / \mathrm{mg}$ と急激な OC 含有量の増加 がみられ，只の後 9 週までわずかに増加していた。

対照群：術後 3 日で $0.6 \mathrm{ng} / \mathrm{mg}$ と OC 含有量の軽度の増 加がみられたが，そ机以降は増加傾向を示さなかった（図4）。

\section{考察}

骨移植術が最初に行われたのは，ヒトの頭蓋骨欠損症例 に対してイ又頭蓋骨を移植した異種骨移植である ${ }^{5)}$ 。のの 後は，同種骨移植ならびに自家骨移植について多くの実験 


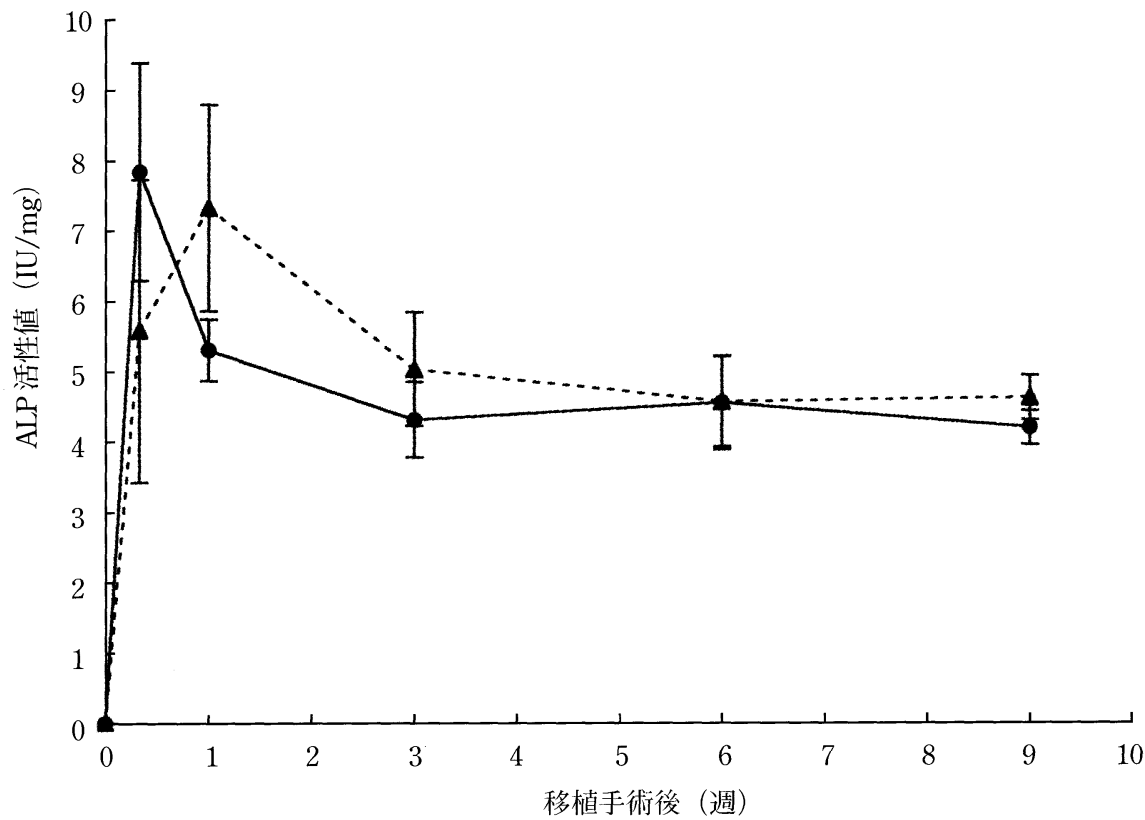

図 3 アルカリフォスファターゼ (ALP) 活性

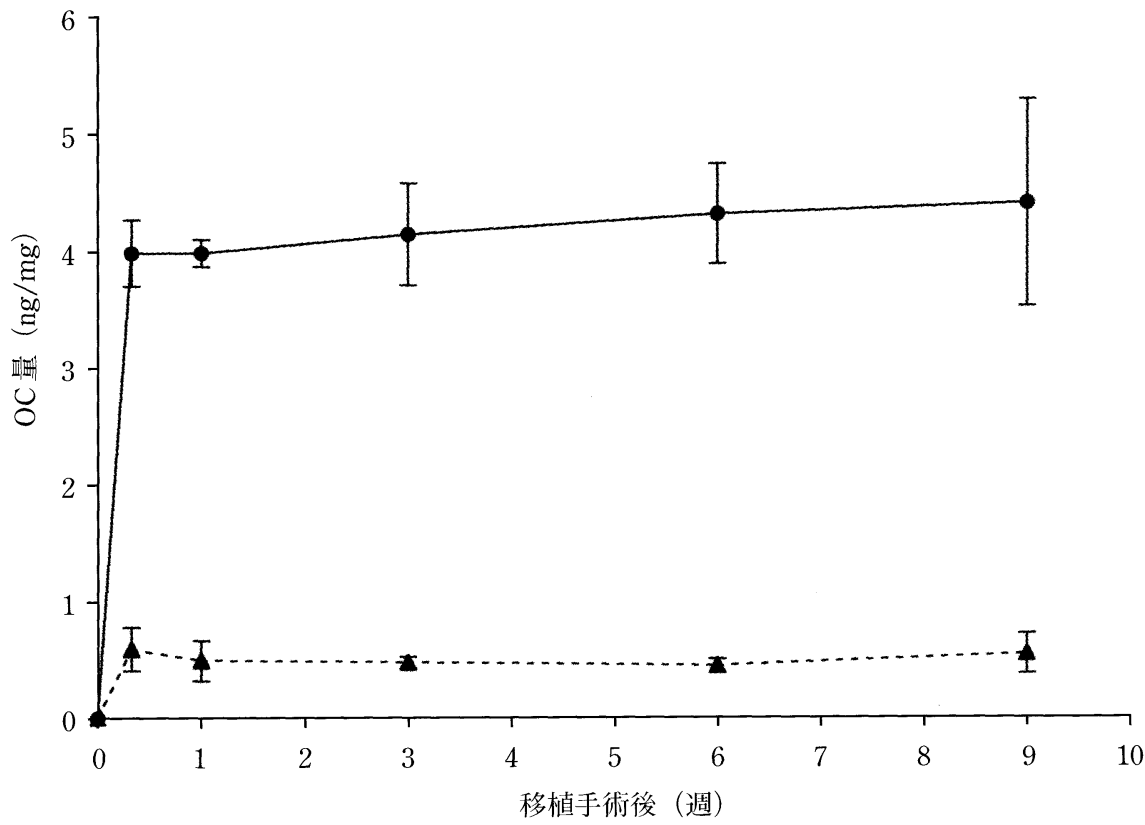

図 4 オステオカルシン $(\mathrm{OC})$ 含有量

的研究が報告されている $4,25,26)$.しかし，これらはいずれ も遊離骨移植術に関する報告が主である。通常，いったん 遊離された骨片においては血流が遮断され毛細血管は閉塞 し，移植床の血管との吻合は行われなくなる ${ }^{27)}$ 。また，骨 細胞が短期間で死にいたるため骨吸収が起こり，骨誘導能 も著しく阻害されることから生着が不利とされている ${ }^{28)}$. これらの久点を補うために考案された有茥骨移植術は，採
取部位や移動量などに臨床上の制限があるが，移植された 骨組織は生存性を保持していることから周囲骨との生着が よく，感染ならびに移植骨の吸収が少ないという点で，遊 離骨移植に比べ優れた移植法とされている ${ }^{29)}$ 。一方，微小 血管外科の発展により，最近ではいったん血行が遮断され た骨片に対して再度血流を再開させることができる移植方 法が可能となったが，これも移植骨片を自家に求めるため 
採取部位や採取量に制限がある。また，採取部位に新たな 欠損を作ることにもなる．最近，これらの問題を解決する ために自家の細胞と生体材料とを組み合わせて生体組織の 再生を四る，tissue engineering ${ }^{6)}$ の技術が進歩してきた. Yoshikawa $5^{18 ） や 夫 ら ~}{ }^{15 ）}$ はラット骨髄細胞を生体材料 内で培養後，ラット背部皮下に移植した結果，骨形成が確 認されたと報告している。 また，朝村 ${ }^{30)}$ はイヌ骨膜細胞 を培養後, 細胞/フィブリン複合体を作製しヌードマウス 背部皮下に移植したところ，骨組織の形成が確認できたと 報告している。しかし，これらの培養骨は組み合わせた生 体材料により，その足場となる材料が吸収せずに残存する. また，血流を保持していないことから，母床の状態が悪い 場合，移植骨が生着しない可能性もでてくる。したがって， 足場に生体吸収性材料を用い，かつ培養骨への血液供給が 保持できればこれらの問題も解決できると考えられる.

一方で，以前より prefabricated vascularized bone graft に関する研究が行われてきた．杉本 ${ }^{19)}$ はラット伏在動・ 静脈を茎とする血管柄付き骨膜と骨髄液入りアテロコラー ゲンスポンジとを組み合わせ， tubed flap を作製し腓腹筋 筋膜上に移植した結果，旺盛な骨形成を確認し，移植骨片 としての有用性を述べている．また，北郷ら ${ }^{20,21)}$ はラッ 卜大腿動・静脈に生体吸収性膜を巻き，その中に自家骨髄 海綿骨細片を充填したところ，良好な血行を保持した血管 柄付き移植骨片が二次的に作製できたと報告している.

そこで今回，新たに prefabricated vascularized bone graft 作製の研究に tissue engineering の技法を取り入れ，自家 の細胞と生体材料とを組み合わせ，二次的血管柄付き移植 骨片の作製を試みた。本研究で確立した移植骨片作製方法 は，自家の骨髄細胞，血管束および生体材料を組み合わせ て行うため，生体への侵襲は骨髄採取と血管束の犠牲のみ に留めることが可能となり, 臨床応用の際に患者への負担 が大幅に軽減される，また今後，血管再生の技術が確立さ れれば，血管束の犠牲もなくなると予測される.

本研究の実験群では術後早期から骨の形成が認められ， さらに経時的に新生骨の増加と成熟が確認された。一方, 血管束を用いなかった対照群の骨形成は実験群に比べ著し く少なかった。こてれは実験群 diffusion chamber に通した血 管束より新生毛細血管網が派生し，骨形成に良好な血流を 提供したからと考えられる，なお，実験群において術後 6 週以降で骨形成量の減少を認めたが，これはメカ二カルス トレスの不足によるものと考えられる.

生化学的分析において ALP 活性は骨形成のより初期の 段階で上昇し，骨分化のマーカーとして考えられている ${ }^{31}$. 一方，OC は骨の非コラーゲン性タンパクのなかでも非常 に量が豊富で，骨の成熟とともに増加することが報告され ている ${ }^{32)}$. Yoshikawa ${ }^{33)}$ は骨髄細胞とヒドロキシアパ
タイトとの複合体をラット背部皮下に埋め込み，骨形成過 程を組織学的および生化学的に検索している。その結果， ALP 活性が早期に上昇し，OC 含有量が経時的に増加する ことから，異所性の骨形成を確認している。そして，ALP 活性と OC 含有量は骨形成評価に有用な指標であると報告 している. 本研究における実験群のALP 活性值は術後 3 日 で約 $8 \mathrm{IU} / \mathrm{mg}$ と上昇した後漸減し，術後 1 週からは約 5 $\mathrm{IU} / \mathrm{mg}$ とほぼ一定であった。また，OC含有量は術後 3 日 で約 $4 \mathrm{ng} / \mathrm{mg}$ と増加し, 以降も軽度の増加を示した. これ らの結果から，実験群では良好な骨形成が行われているこ とが推察された. 対照群に打いても ALP 活性值は術後早期 から上昇していたが，これは diffusion chamber 内に骨芽細 胞を充填しており，軽度の骨形成がみられたためと考えら れる。ささら，実験群に打いて兔疫組織化学的に骨髄組織 にも OCの陽性反応が観察されたが，これは骨芽細胞によ り産生された OC が骨基質に取り込まれ，そしてそのほと んどが骨髄中に放出されるため，それを検出したものと考 えられる.

一般に tissue engineering では，細胞と細胞の足場およ び調節因子が重要な三要素であり，さらにそれらの複合体 が置かれた環境により組織が再生されるとしている。本研 究では細胞，そして細胞を播種したコラーゲンスポンジと diffusion chamber が足場となり，それに組み合わせた血管 束が調節因子として機能した結果，骨形成に対し促進的に 働き，上述したような形態学的抢よび生化学的結果が得ら れたと考えられる。このことは，血管束を用いなかった対 照群で骨形成が著しく少なかったことの裏付けになると思 われる。

異所性に骨を作製する際，周囲からの軟組織の侵入を防 き，骨形成の足場を確保するためにスペースが必要となる ${ }^{21)}$. 今回用いた diffusion chamber は, プラスチックリングの両 面にメンブレンフィルターを接着したもので，内部に細胞 や組織を閉じこめ，それを動物の体内に埋め込んで in vivo 培養を行う培養ユニットである. メンブレンフィルターに よって宿主遊走細胞は diffusion chamber 内へ侵入できな いが，宿主動物の体液は自由に通過可能で，封入された細 胞，組織は増殖することができる。また，足場として用い る生体材料に細胞を播種する際，生体材料の表面に細胞は 接着するが，その内部にまで細胞を浸透させることは困難 で，振とう培養などの技術が必要となる。しかし，コラー ゲンスポンジでは注射針を用いて容易に細胞をスポンジ内 部に注入することができるので，スポンジ全体に細胞を播 種することが可能である. さらにコラーゲンスポンジは生 体吸収性であるため，新生骨が形成される一方で，コラー ゲンは吸収され骨に置換されていく，これらのことより， 本研究で用いた diffusion chamber とコラーゲンスポンジ 
とは骨形成の足場として優れた組み合わせであると考えら れる。

さらに，形成された血管柄付き移植骨片は diffusion chamber 形態にほぼ一致し, 容易に diffusion chamber から 外すことができた。したがって，あらかじめ必要とされる 移植骨片の大きさに diffusion chamber の形態を合わせて おけば，理想的な形態を有する移植骨片が作製できると考 えられる，また，移植骨片を骨欠損部に移植する 2 次手術 の際，異物となる diffusion chamber を容易に外すことが可 能で，手術時間を短縮することができる.

以上のことから, diffusion chamber を利用して骨髄細胞, コラーゲンスポンジおよび自家血管束を組み合わせること で，良好な血流と骨形成能を保持した血管柄付き移植骨片 を二次的に作製できることが判明した。これは理想的な形 態を自由に付与することが可能で，さらにあらゆる移植床 に応用することができ，きわめて有効な骨移植術となるこ とが示唆された。

結語

䫟骨再建のための骨移植術として, tissue engineering の 技法を用い，自家の骨髄細胞から血管柄付きの再生培養骨 を作製した。これは生体への侵襲を著しく軽減した方法で, 近い将来臨床における有用な骨移植術となる可能性をもっ ている.

本研究は大阪菌科大学中央茵学研究所動物施設を使用した. また, 本研究に打ける実験動物の取り扱いに関しては, 「大阪 菌科大学動物実験に関する指針」を遵守して行った。

なお，本研究に打ける動物実験承認番号（大阪菌科大学動 物実験委員会）は第 04-02024 号である.

\section{謝辞}

稿を終えるにあたり，直接のご指導を賜りました大阪菌科 大学口腔外科学第 1 講座 杉本圭介博士ならびに北郷明成博 士に心より御礼申し上げますとともに，終始㤠親なるご指導 をいただきました大阪菌科大学口腔外科学第 1 講座 浦 栄 吾博士ならびに井上明洋博士に厚く御礼申し上げます。

また, 免疫組織化学的検索にあたりご指導を賜りました大 阪菌科大学口腔病理学講座 富永和也博士に深謝いたします。 さらに，画像処理等にご協力いただきました大阪雨科大学中 央菌学研究所技術員 堀 英明氏に謝意を表します。

研究を始めた当初, 直接のご指導を賜りました大阪菌科大 学口腔外科学第 1 講座 故久保誼修講師（当時）に本論文を 捧げます。

本論文の要旨の一部は, 第 58 回日本口腔科学会総会 (2004 年 5 月, 横浜市）にて発表した.

\section{引 用 文 献}

1) Weiland, A.J., Philips, T.W., et al.: A radiologic, histologic and biomechanical model comparing autografts, allografts and free vascularized bone graft. Plast Reconstr Surg 74: 368-379 1984.

2) Taylor, G.I.: The current status of vascularized bone grafts. Clin Plast Surg 10: 185-192 1993.

3) DeLuca, L., Raszewski, R., et al.: The fate of preserved autogeneous bone graft. Plast Reconstr Surg 99: 1324-1328 1997.

4) Lane, J.M. and Sandhu, H.S.: Current approaches to experimental bone grafting. Orthop Clin North Am 18: 213-225 1987.

5）杉岡洋一: 骨移植の歴史と展望. 形成外科 35: 1191241992.

6) Langer, R. and Vacanti, J.P.: Tissue engineering. Science 260: 920-926 1993.

7）上田 実：再生医学とティッシュエンジニアリン グー茵科治療に扑ける可能性一. The Quintessens 20: 71-83 2001.

8) Johnson, K.A., Howlett, C.A., et a1.: Osteogenesis by canine and rabbit bone marrow in diffusion chambers. Calcif Tissue Int 42: 113-118 1988.

9) Bab, I., Ashton, B.A., et al.: Kinetics and differentiation of marrow stromal cells in diffusion chambers in vivo. J Cell Sci 84: 139-151 1986.

10) Ashton, B.A., Allen, T.D., et al.: Formation of bone and cartilage by marrow stromal cells in diffusion chambers in vivo. Clin Orthop 151: 294-307 1980.

11) Dohi, Y., Ohgushi, H., et al.: Osteogenesis associated with bone gla protein gene expression in diffusion chambers by bone marrow cells with demineralized bone matrix. J Bone Miner Res 7: 1173-1180 1992.

12) Picha, G.J. and Levy, D.: Microvascular A-V shunts and the growth of autologous tissue flaps in millipore chambers. Plast Reconstr Surg 87: 509-517 1991.

13）成 耆徹：既存の動静脈血管束を用いた prefabricated engineering skin flap についての実駼的研究. 日形会誌 22: 440-448 2002.

14）田中嘉雄，成 耆徹，他：既存の動静脈血管束を用 いた prefabricated engineering skin flapに関する実 験的研究一第 2 報一. 日形会誌 23: 412-422 2003.

15）夫才成, 日比野祥敬, 他: 生体吸収性セラミック ス $\beta$-TCP を足場に用いた培養人工骨に関する実験 的研究. 日口外誌 47: 1-7 2001.

16) Ohgushi, H., Dohi, Y., et al.: In vitro bone formation by rat marrow cell culture. J Biomed Mater Res 32: 333-340 1996.

17) Maniatopoulos, C., Sodex, J., et al.: Bone formation in vitro by stromal cells obtained from bone marrow of young adult rats. Cell Tissue Res 254: 317-330 1988.

18) Yoshikawa, T., Ohgushi, H., et al.: Immediate bone forming capability of prefabricated osteogenic hydroxyapatite. J Biomed Mater Res 32: 481-492 1996.

19）杉本圭介：血管柄付骨膜とアテロコラーゲンを用い 
た prefabricated vascularized bone graft 作製に関す る実験的研究. 日口外誌 44: 111-125 1998.

20）北郷明成，久保誼修：生体吸収性膜，自家血管束打 よび骨髄海綿骨細片を用いた顎骨再建に関する実験 的研究. 日口外誌 48: 549-556 2002 .

21) Hokugo, A., Kubo, Y., et al.: An idea of prefabrication of vascularized bone graft using guided bone regeneration. Tissue Eng 2004 (inpress).

22）堀内 薰，久保誼修，他：二次的血管柄付骨移植片 による顎骨再建に関する実験的研究. 日口外誌 49: 423-430 2003.

23) Bessey, O.A., Lowry, O.H., et al.: A method for the rapid determination of alkaline phosphatase with five cubic millimeters of serum. J Biol Chem 164: 321-329 1946.

24) Ohta, T., Azuma, Y., et al.: Measurement of intact rat osteocalcin in osteoblast (ROS17/2.8) cells and in ovariectomized rats with a sandwich enzyme immunoassay. Calcif Tissue Int 59: 283-290 1996.

25) Kaban, L.B. and Glowachi, J.: Induced osteogenesis in the repair of experimental mandibular defects in rats. J Dent Res 60: 1356-1364 1981.

26) Goldberg, V.M., Powell, A., et al.: Bone grafting: role of histocompatibility in transplantation. J Orthop Res 3: 389-404 1985.
27) Ray, R.D.: Vascularization of bone grafts and implants. Clin Orthop 87: 43-48 1972.

28) Urist, M.R., Iwata, H., et al.: Bone morphogenesis in implants of insoluble bone gelatin. Proc Nat Acad Sci 70: 3511-3515 1973.

29) Mogi, G., Fujiyoshi, T., et al.: Latissimus dorsi myocutaneous-iliac bone flap for reconstruction of massive defects of mandibular and oral basis. Laryngoscope 96: 171-177 1986.

30）朝村真一：培養骨膜細胞とフィブリン複合体を用い た骨のティッシュ エンジニアリング．近畿大医書 25: 183-198 2000.

31) Weinreb, M., Shinar, D., et al.: Different pattern of alkaline phosphatase, osteopontin, and osteocalcin expression in developing rat bone visualized by in situ hybridization. J Bone Miner Res 5: 831-842 1990.

32) Price, P.A., Williamson, M.K., et al.: Characterization of matrix gla protein. A new vitamin K-dependent protein associated with the organic matrix of bone. The chamistry and biology of mineralized tissue. Ebsco Media, Birmingham, 1985, p159-163.

33) Yoshikawa, T., Ohgushi, H., et al.: Biochemical and histological sequences of membranous ossification in ectopic site. Calcif Tissue Int 50: 184-188 1992. 